УДК 94(47)

DOI: 10.30914/2227-6874-2018-11-180-191

\title{
Features of teaching of the scientific corporation at the Higher Women's (Bestuzhev) Courses in 1878-1918
}

\section{O. B. Vakhromeeva}

The Higher Women's (Bestuzhev) Courses in St. Petersburg (Petrograd), which existed from 1878 to 1918 , and in 1919 were merged with the former Imperial (First Petrograd) University. In historiography they are rightly called the female faculty of the university. The reason for this was the continued support of the faculty of the male university of a private higher female educational institution. It should also be noted the similarity of the construction of the educational process and almost identical (with rare exceptions) curricula of both universities. The Bestuzhev Courses for many professors and teachers were the place of the creative laboratory (women's universities were often invited to teach the best specialists in their field, not paying attention to their young age, track record or dismissal due to their disagreement with the policy of a particular minister of public education). Since the teaching activity was for many of them the main sphere of self-realization, at the private women's university they received a significant base and wide opportunities. The Bestuzhev Courses were famous for their democratic traditions. The instructors played a leading role in conducting fundamental research and creating scientific schools. By this, they contributed not only to the unity of the male and female academic audience, but also had a beneficial effect on the development of scientific knowledge themselves. Higher Women's Courses had excellently equipped scientific laboratories, classrooms, and extensive library collections, which particularly influenced the development of applied research. In addition, the academic corporation, which dealt with young, talented, hardworking young women, had the opportunity to educate a unique pleiad of the first Russian female scientists who continued the scientific traditions of their Alma mater in their professional activities within the walls of the Highest Women's (Bestuzhev) Courses.

Keywords: St. Petersburg (Petrograd) Higher Women's (Bestuzhev) Courses, S. B. Okun', corporation of scientists, university studies.

Citation for an article: Vakhromeeva $O . B$. Features of teaching of the scientific corporation at the Higher Women's (Bestuzhev) Courses in 1878-1918. WestEast. 2018, no. 11, pp. 180-191. DOI: 10.30914/2227-6874-2018-11-180-191

\footnotetext{
(C) Вахромеева О. Б., 2018
} 
The Higher Women's (Bestuzhev) Courses in St. Petersburg, the first women's university in the Russian Empire, were founded in 1878, existed for 40 years and in 1919 were merged with the First Petrograd (last Imperial) University. The Courses were prepared by the first Russian women-scientists and women-teachers [12, p. 43].

The Bestuzhev Courses were the private higher education institutions. They were financed by the activities of "The Society for the Delivery of Funds to the St. Petersburg Higher Women's Courses", which existed in parallel with the Courses ${ }^{1}$. Contemporaries often called The Higher Women's Courses "the fifth" or "female" faculty of the Imperial University in the capital of the Russian Empire. The reason was, on the one hand, in seeking Russian women receive higher education on an equal basis with men, and, on the other hand, in helping of professors and teachers of the Imperial University and other higher educational institutions of St. Petersburg in the upbringing and education of women.

For the first time in the history of the issue, Leningrad historian, professor at Leningrad State University Semion Benzianovich Okun' (1908-1972) drew attention to the support of progressive scholars of the idea of higher female education in Russia. In 1968, he was instructed to give a speech in the Assembly Hall of the University to celebrate the 90th anniversary of the first women's university in Russia. The meeting was organized by the women-graduates of the Bestuzhev Courses, which have created public organizations in Leningrad, Moscow and Paris to preserve memory of their Alma mater, their teachers, to assist sick and alone comrades. They wrote the memoirs, collected archive (named "Foundation for the Higher Women's Courses") and held annual and anniversary meetings in Moscow and Leningrad [2, c. 6-11]. The historian S. B. Okun', along with scientific advice on systematization of the archive of the women-graduates of the Higher Women's Courses, at the Faculty of History led the work on the history of St. Petersburg University (he was one of the authors of the "History of the Leningrad University") [9, c. 74-79].

S. B. Okun' titled his performance "'Commendable word' to the Bestuzhev Courses"2. The historian called the most progressive higher educational institution in Russia, the Higher Women's Courses "the brainchild of the university". He noted the unity of boy-students and girl-students at the turn of the XIX-XX centuries and the special role of professors and teachers of the female university. "At the Bestuzhev Courses the best part of the university professor was given the opportunity to develop her own teaching activities with greater freedom. The Courses formally had nothing to do with the university, but university professors were fully responsible for them" [3, c. 95]. Experiencing endless difficulties in

\footnotetext{
${ }^{1}$ S.-Peterburgskie Vysshie zhenskie kursy za 25 let. 1878-1903. Ocherki i materialy. SaintPetersburg, 1903, p. 76-77.

${ }^{2}$ Arkhiv Muzeya istorii Sankt-Peterburgskogo gosudarstvennogo universiteta, f. Higher Women's Courses, d. Protocol of the meetings of the Leningrad Committee. Protocol number 7 for 1970, 1. 13.
} 
their work, being systematically persecuted in the reaction press, in the end, professors and organizers of the Courses were victorious in the struggle to create higher female education in Russia. S. B. Okun' said: "The list of professors who worked on the Courses could rightfully be called 'Glory and Pride of Russian Science': Ainalov, Beketov, Baudouin de Courtene, Vasilievsky, Vvedensky, Greavs, Kotlyarevsky, Mendeleev, Tarle, Favorsky, Grekov, Presnyakov and many others. One of the professors, a graduate of our university, said that when he had been a student, he often had gone with his friends to the Bestuzhev Courses to listen to lectures, because there "professors read otherwise". The Courses were creative. Here it was possible and necessary not just to give a lecture but also to rethink it creatively. Of particular note is the use of seminars that have developed into serious scientific meetings. The reports that were made there were the result of serious work on the material, and the method of conducting gave excellent preparation for scientific work" [3, c. 97].

The scientific corporation of the Bestuzhev Courses belonged to the cultural phenomenon of the pedagogical environment of pre-revolutionary Russia. This is evidenced by the monographic study of the author of an article on teaching science at the Higher Women's Courses [6] published in 2018 to the 140th anniversary of the Courses (1878-1918), which for the first time in the history of studying courses presented a detailed list (539 personalities) of professors and teachers of the Bestuzhev Courses over 40 years. The list contains surnames, first names, patronymic names, years of life, a short scientific biography and characteristics of lecture courses and practical classes that they taught at the women's university [6, c. 353-477].

This scientific study has no analogues in Russia. However, the historiographic tradition knows a number of studies, including the peculiarities of teaching a number of disciplines in specialized educational institutions (in the newest historiography, mention should be said about the fundamental work of professor A. E. Ivanov about the certification system of scientific and pedagogical personnel of the higher school of the Russian Empire of the 18th - early 20th century [8] and E. A. Rostovtsev about the academic class of Petersburg University and its relationship with society and government [10]; also should be made of the article by V. G. Ananiev about the Institute of Art History) [11, p. 9-20].

The higher women's school in Russia was focused on the Imperial University; therefore, it largely repeated its teaching and research structure, adopted the system of classes, and copied the relationship of the teaching corporation with the students. Although the Bestuzhev Courses as a higher education institution for women had important features. Teachers at the Imperial University and on the Bestuzhev Courses did not distinguish their professional activities, but in private Courses they could expand the horizons of their teaching [2, c. 105-106]. 
Pedagogical work as a special kind of highly skilled mental activity of a creative nature has always been distinguished by an extreme degree of tension. Therefore, memories of teachers, the women-graduates of the Courses wrote about the brilliant actor's and oratorical qualities of the lecturers, their manner of keeping in front of and outside the audience, the high intensity of classes and noted one or another system of their teaching.

Teaching on the Bestuzhev Courses was not easy. The female students are young women (of different ages, religions, social backgrounds, graduates of various secondary, and sometimes higher, educational institutions) who came to the capital from the far corners of the Russian Empire. They were gifted and purposeful (with their own individual qualities). In the courses, young women were under the influence of various factors and people under whose influence they changed. Surrounding people - all personalities "with a capital letter" - the organizers and teachers - who possessed not only high professional qualities, but were able to convince, direct, captivate the younger generation. Teachers opened the way for women to theoretical and practical knowledge, methodological and organizational work. Therefore, the Bestuzhev Courses are the place of a creative laboratory where new personalities of women scientists and women teachers were formed. The women-graduates of the Courses tried to be like their professors and teachers. In their professional activities, they carried the light to people, noting that they turned on during their studies at the Bestuzhev Courses [6, p. 350-352].

So, the first feature of teaching a scientific corporation at the Bestuzhev Courses was to find the format of knowledge that professors and teachers passed on to an exclusive female student audience.

For example, at the time of the opening of the Bestuzhev Courses, the fear was that in the late $1870 \mathrm{~s}$ - early $1880 \mathrm{~s}$, the knowledge of the majority of female students in the first year did not correspond to the university level. The program of the training course for female gymnasiums, whose task did not include preparing girls for entering higher educational institutions, and which was significantly inferior to the course of men's gymnasiums, was to blame for everything ${ }^{1}$. But the Ministry of Public Education, without showing any special imagination, transferred to the Higher Women's Courses in 1878 almost all the subjects that were studied at the Imperial University under the statute of $1863^{2}$.

The first-year curriculum of the Higher Women's Courses presented serious demands to former schoolgirls and home girl-teachers. For example, in order to enter the special-mathematical department, it was necessary to withstand the tests of a complex program. On the first course: on geometry - the course of the initial geometry in the volume of the course of men's gymnasiums (to stereometry);

\footnotetext{
${ }^{1}$ Central State Historical Archive of St. Petersburg, f. 113, op. 1, d. 7650, 1. 1-7.

${ }^{2}$ Central State Historical Archive of St. Petersburg, f. 113, op. 1, d. 6874, 1. 23-23 rev.
} 
in arithmetic - the whole course; on algebra - an algebra course in the program of men's gymnasiums (up to square equations). For admission to the second course, students had to undergo tests throughout geometry and arithmetic (in the volume of the course of men's gymnasiums); from algebra - everything except quadratic equations and progression. The girl-students who graduated from the special mathematical department easily passed examinations for the title of female mathematics teachers in the upper grades of gymnasiums ${ }^{1}$.

Having overcome considerable difficulties, showing strength of will and character, as well as feeling support from professors and teachers, who organized additional classes in a number of disciplines in order to eliminate the difference between the programs of male and female secondary schools - the first (1882) and second women-graduates (1883) issues were the first pride of Russian science. Under Bestuzhev courses were left to teach: the mathematician Vera Iosifovna Schiff, the physicist Anna Eliseevna Serdobinskaya, the historian Elena Nikolaevna Schepkina, the paleontologist Eugenia Viktorovna Solomko, the zoologist Maria Aleksandrovna Russiyskya (Kozhevnikova).

But time went by. And in 1892, girl-students of the Physics and Mathematics Department organized the Publishing Committee, which was engaged in lithography of lectures of individual teachers and professors. Published lectures were used by students of the Imperial University and girl-students of the Bestuzhev Courses. In 1903, girl-students of mathematics asked professors to open a mathematical reading room, "where students could find the necessary aids on subjects of the course and on special issues; here to deal with these benefits" .

Young women were attracted to the natural sciences. Alexander Mihailovich Butlerov (1828-1886), a professor of inorganic chemistry, to support their scientific interest, put chemistry teaching at the Bestuzhev Courses on a solid foundation. In 1880, he organized the first chemical laboratory for women (a fume hood was placed on the stove, a hydrogen sulfide appliance was placed in the oven, and a distillation cube was in place of the boiler). The room was small (48 square meters), with a height of $3 \mathrm{~m}$; at the same time students were engaged in it. When in 1885 the Courses moved to their own building (10th line of Vasilyevsky Island, house number 33), an extensive chemical laboratory was organized there, organized according to the latest science ${ }^{3}$. A. M. Butlerov was among those professors who was not only an excellent specialist and a worldfamous scientist, he was also a supporter of women's higher education.

\footnotetext{
${ }^{1}$ Women's education. 1879. № 6-7. P. 458-459.

${ }^{2}$ Materials of the personal archive N. V. Blagovo. Materials E. Yu. Mel'nikova, d. Mathematical reading room, 1.1 .

${ }^{3}$ S.-Peterburgskie Vysshie zhenskie kursy za 25 let. 1878-1903. Ocherki i materialy. SaintPetersburg, 1903, p. 103.
} 
Professors-astronomers of the Bestuzhev Courses (A. M. Zchdanov, I. I. Ivanov, A. A. Belopol'sky), who for the first time in the world (!) created a unique scientific base for women in the study of celestial bodies and astronomical phenomena, can be called advanced teachers. The women-graduates worked in many Russian, Soviet and foreign astronomical scientific institutions. In 1910, the Astronomical section was established at the female university, where lecturers and students from other universities of St. Petersburg and Petrograd came to give lectures and to do report. Astronomer Sofya Vasilyevna Romanskaya-Voroshilova pointed to the special creative atmosphere of the Astronomical section, and considered all women-graduate astronomers to be members of a large friendly "Bestuzhev-family".

The second peculiarity of teaching at the Bestuzhev Courses can be attributed to the folding of the special behavior of professors and teachers in the women's higher education institution. Many of them sought to get to the Bestuzhev Courses in order to become part of the creative atmosphere that distinguished the Courses. About this there are numerous testimonies of both teachers and women-graduates. But we should stop at the bottom of the celebration of the 30th anniversary of the scientific activity of professor Sergey Konstantinovich Bulich (1859-1921), who was the director of the Bestuzhev Courses from 1910 to 1918.

Woman-graduate E. Yu. Mel'nikova wrote: “On September 24, 1913, a photographer came to the courses and took a photo of us with Sergey Konstantinovich before his lecture to the XII lecture hall. This jubilee was marked in the press and solemnly celebrated in our courses. In the press, Sergey Konstantinovich was spoken of not only as a linguistic scholar, but also as a musical critic. As a scientist, teacher and administrator, S. K. Bulich at the same time was a music theorist and played the piano well. Very often with his game he satisfied the aesthetic aspirations of his listeners. I remember how well he recited poems and played the piano" [4, c. 106].

On the day of his jubilee celebration, the professor accepted congratulations. The ceremonial, bright, warm and grateful speeches of his colleagues and girl-students sounded in the assembly hall of the Bestuzhev Courses. Congratulatory addresses were read out: "Sergey Konstantinovich is a supporter of the higher education of the women and the autonomy of our university, an exceptionally handsome man. He has held a difficult and responsible post for many years. The female students, coming to him, meet with sympathetic participation, and not a dry, purely formal answer. He goes to meet the artistic interest of listeners, delivering aesthetic pleasure to his music" [4, c. 107]. "Zina Plotnikova read the address from the present and former participants of his seminary. She welcomed him as a beloved teacher and thanked him for his attentive and cordial attitude to them during the classes. Anya Khvalynskaya presented

\footnotetext{
${ }^{1}$ Arkhiv Muzeya istorii Sankt-Peterburgskogo gosudarstvennogo universiteta, f. Higher Women's Courses, d. 1821, 1. 1 rev. -2 rev.
} 
a bouquet of roses from the seminary" [4, c. 108]. The professor answered every greeting with a speech. "In response to a common exchange address, he called us friends and gave us a 'covenant' to remember that love is creative, not hatred; said that he really always tried to do everything he could for the students of the courses. He believes that a bright future belongs to a woman in the country's cultural work. He apparently met our seminar address with particular sympathy and said that in seminaries the professor was more intimate with the female students and he could forget what disturbed him when working with them" [4, c. 108-109].

At $8 \mathrm{pm}$, a banquet was appointed, which was attended by about 200 people. S. K. Bulich continued to accept congratulations, a musical and literary concert was arranged. "When all the speeches were over, girl-student E. M. Voronkovskaya said: 'Dear Sergey Konstantinovich! You have so often arranged for us literary evenings, let us at least once arrange a literary and musical evening for you'. The concert began. The audience is freely located anywhere: who was still sitting at the table and drank tea, who sat aside and listened to who was standing. The picture was very attractive. She wore such a family character. Sergey Konstantinovich sat first at the table, and then moved closer to the stage, to the female students. There was a piano on the stage. Listeners acted with recitation. Guest artists sang to the accompaniment of a grand piano. One student played the violin wonderfully. At the end of the evening they asked Sergey Konstantinovich to play the piano - and he played. The photographer filmed us on the background of the stage". The celebration ended well after midnight. Students and professors accompanied S. K. Bulich stormy applause $[4$, c. $109-110]$.

The peculiarities of teaching at the Bestuzhev Courses should include the idea of uniting the male and female student audience within one or several laboratories, or within the boundaries of this practical workshop.

Professor Aleksey Evgrafovich Favorskiy (1860-1945) was invited to the Bestuzhev Courses for classes with the third year girl-students, whom he taught organic chemistry four hours a week. A world-renowned scientist at first did not know what role the women's university would play in his fate. Like his predecessors, he began with the device of the laboratory of organic chemistry, which he converted and equipped again. As a professor at the Imperial University, he did not see the difference in which room his students worked in the male and female university. Therefore, the laboratories of the two universities were arranged in the same way. Quite often, his students worked on the same scientific tasks in parallel, which led to the merging of male and female student audiences and led to the creation of a single scientific school in organic chemistry of academician A. E. Favorskiy. Dozens of graduates of St. Petersburg University and the same number of Bestuzhev's graduates could rightfully call themselves "students of Favorskiy" [5, c. 20-22]. 
Women chemists had the opportunity not only to gain knowledge in a complex subject, but also to master all scientific methods. Such a teaching is called "academic freedom"1.

Many scientific works of students A. E. Favorskiy reported at the meetings of the Russian Chemical Society and published in his journal. The professor loved his students and always cared about their employment. Three employees of Favorskiy's Bestuzhev Courses (M. A. Ageeva, V. I. Egorova, A. I. Umnova) received the Butlerov's medal for their scientific works. T. D. Velichkovskaya recorded the first course of lectures by the professor. A. E. Favorskiy left several dozens of women chemists behind him, many of whom became Ph. D. 6 candidates, increasing the fame of the scientific school of teachers with their activities [7, c. 269-270, 277-278].

At the Higher Women's Courses, as well as at the Imperial University, there was a tradition of combining practical (seminar) classes with "near" and "far" excursions. For example, B. D. Grekov conducted annual excursions in Novgorod. In 1910, F. F. Zelinskiy and his students visited Greece. Excursions to the ancient Russian cities (Vladimir, Suzdal', Kiev, Old Ladoga, Valday) were organized by B. D. Grekov, D. V. Ainalov, I. A. Shliapkin and S. F. Platonov. B. V. Farmakovskiy, with the most permanent members of the audience, made annual expeditions to Olvia. I. M. Greavs traveled to Italy twice with his students from the university and Courses (1907 and 1911). Trips and excursions caused genuine interest and appreciation of students and girl-students.

Professor Ivan Mikhailovich Greavs (1860-1941) was the ideologue, theorist and practitioner of the excursion method of teaching in middle and high school in pre-revolutionary and Soviet Russia. Scientific trips, according to the curriculum, stood apart from the main educational process, despite frequent attempts to introduce elements of long-distance excursions into the system of historical education. Successful travel practice was largely dependent on the personal experience of managers. The organizers of historical excursions each time, setting serious scientific goals, were forced to dwell very carefully and in detail on questions of the subject, plan and form of travel, since there was no single type of historical journey.

A "far" trip (excursion) could be made only by those of the students and girl-students of professor I. M. Greavs on Courses and at the university, who could pay for it, as well as those who successfully passed the practical tasks on the general history and passed the necessary tests (reading texts of sources in the original language and their translation). Travels in Italy were undertaken not to provide participants with "elevated rest" after a year's work, but with the aim of continuing the work begun among the "laboratory" setting of the seminary. This was one of the ways to teach the skill of the historian, who

\footnotetext{
${ }^{1}$ S.-Peterburgskie Vysshie zhenskie kursy za 25 let. 1878-1903. Ocherki i materialy. Saint-Petersburg, 1903, p. 111.
} 
I. M. Greavs formulated as: "from books to monuments, from office to the real scene of history from a free historical air again to the library and archive!"1.

The routes of the two collective trips in Italy were almost the same. Their participants visited Venice, Padua, Ravenna, then moved to Tuscany, where they stayed for a long time in Florence and nearby cities (Pisa, Siena, Lucca, Prato), then went to Umbria, where they certainly examined Perugia, Assisi and last they visited Rome.

Guided by the indisputable principle of scientific research, the organizers of the trips provided students and girl-students with a unique opportunity to refer to the source - documentary and monumental, comprehending the authentic traces of antiquity. Written and oral works of the human mind were supplemented with real monuments of art and labor, due to which an opportunity arose to apprehend the essence of evidence from a written source. The professor believed that a complex of specific data (ideas, beliefs, searches, embodied in the observation with the immediate eye of diverse archaeological monuments of art and life in a natural setting that grew them, gives a bright and sparkling life in one day to a long chain of facts painful effort sought in heavy and thick folios and remaining foggy.

Thus, the main merit of the method of Ivan Mikhailovich Greavs was the rapprochement of seminars (with students of St. Petersburg University, girlstudents of the Bestuzhev Courses) and excursion practice. Students had the opportunity to complete informational perception, as well as experiences of already established ideas about a particular object on the place. As a result of the historical trips, an emotional sensation and a moral sense of conquering the historical Olympus arose. Being a true supporter of enlightenment, on the basis of his pre-revolutionary excursion experience I. M. Greavs developed a "travel formula", placing it in a methodological scheme, which made a significant contribution to the psychology of "humanitarian excursion studies" [1, c. 49-50].

The features of teaching the scientific corporation of the Bestuzhev Courses on the attraction of four decades, which lie on the principles of supporting the women's university and the unification of the Imperial University and the Courses, allowed professors and teachers to exercise control over the academic field in pre-revolutionary Russia.

\section{References}

1. Vakhromeeva O. B. Priglashenie k puteshestviyu: metodika istoricheskih poezdok I. M. Grevsa [Invitation to travel: a method of historical travel Greavs]. Saint Petersburg: Znamenitye universanty Publ., 2007, 56 p. Available at: https://elibrary.ru/item.asp?id=20268751 (accessed 15.06.2018). (In Russ.).

2. Vakhromeeva O. B. Duhovnoe prostranstvo universiteta. Vysshie zhenskie (Bestuzhevskie) kursy 1878-1918 gg.: issledovanie i materialy [The spiritual space of the university. Higher female (Bestuzhev) courses for the years 1878-1918: research and materials]. Saint Petersburg: Diada Publ., 2003, 253 p. Available at: https://elibrary.ru/item.asp?id=20272970 (accessed 15.06.2018). (In Russ.).

\footnotetext{
${ }^{1}$ Greavs I. M. To the theory and practice of "excursions", as an instrument of the scientific study of history in universities. SPb.: Senate typography, 1910. P. 11, 15, 18-19.
} 
3. Vakhromeeva O. B. Ih dan' Bestuzhevskim kursam (ob»edinennaya deyatel'nost' v 50-70-e gody XX veka) [Their tribute to the Bestuzhev courses (joint activity in the 50s-70s of the 20th century)]. Saint Petersburg: Lema Publ., 2015, 444 p. Available at: https://elibrary.ru/item.asp?id= 25554623 (accessed 15.06.2018). (In Russ.).

4. Vakhromeeva O. B. Vospitannye tradiciej. Vospominaniya byvshih slushatel'nic Bestuzhevskih kursov [Brought up by tradition. Memories of former students of Bestuzhev courses]. Saint Petersburg: Art-Ekspress Publ., 2016. 124 p. Available at: https://elibrary.ru/item.asp?id=27502448 (accessed 15.06.2018) (In Russ.).

5. Vakhromeeva O. B. Himiya i himiki na Bestuzhevskih kursah [Chemistry and Chemists at the Bestuzhev courses]. Saint Petersburg: Art-Ekspress Publ., 2017, 120 p. Available at: https:/elibrary.ru/ item. asp?id=27661291 (accessed 15.06.2018). (In Russ.).

6. Vakhromeeva O. B. Prepodavanie nauk na Vysshih zhenskih (Bestuzhevskih) kursah (1878-1918). So vstupitel'nym ocherkom «Granicy zhenskoj emansipacii v dorevolyucionnoj Rossii»: K 140-letiyu Bestuzhevskih kursov [Teaching sciences at the Higher Women's (Bestuzhev) courses (1878-1918). With an introductory essay "The boundaries of women's emancipation in pre-revolutionary Russia": the 140th anniversary of the Bestuzhev courses]. Moscow: Politicheskaya enciklopediya Publ., 2018, 903 p. Available at: https://elibrary.ru/item.asp?id=35566178 (accessed 15.06.2018). (In Russ.).

7. Egorova V. I. Pervaya nauchno-issledovatel'skaya himicheskaya laboratoriya na VZhK [The first research chemical laboratory on the high-fatty fluids]. In Sankt-Peterburgskie Vysshie zhenskie (Bestuzhevskie) kursy, 1878-1918, 2-e izd. Leningrad: LGU, 1973, pp. 269-278. (In Russ.).

8. Ivanov A. E. Uchenoe dostoinstvo Rossijskoj imperii. XVIII - nachalo XX veka. Podgotovka i nauchnaya attestaciya professorov i prepodavatelej vysshej shkoly [The academic merit of the Russian Empire. XVIII - early XX century. Training and scientific certification of professors and teachers of higher education]. Moscow: Novyj hronograf Publ., 2016, 656 p. Available at: https://elibrary.ru/item.asp?id=28936936 (accessed 15.06.2018). (In Russ.).

9. Margolis Yu. D. Semyon Bencianovich Okun'. Zhizn' istorika, rasskazannaya ego knigami, dokumentami i svidetel'stvami sovremennikov [Semion Benzianovich Okun'. The life of the historian, told by his books, documents and testimonies of contemporaries]. Saint Petersburg: SPbGU, 1993, 87 p. (In Russ.).

10. Rostovcev E. A. Stolichnyj universitet Rossijskoj imperii: uchenoe soslovie, obshchestvo i vlast' (vtoraya polovina XIX - nachalo XX v.) [Metropolitan University of the Russian Empire: the academic class, society and government (the second half of the XIX - beginning of the XX century)]. Moscow: Politicheskaya enciklopediya Publ, 2017, 903 p. Available at: https://elibrary.ru/item.asp?id= 29370832 (accessed 15.06.2018). (In Russ.).

11. Ananiev V. G. The Institute of Art History and the Problem of Aesthetic Education in Russia in the First Quarter of the 20th Century, in Muzeologia a Kulturne Dedicstvo, 2016, no. 2, pp. 9-20. Available at: https://spbu.pure.elsevier.com/ru/publications/the-institute-of-art-history-and-the-problem-ofaesthetic-educati (accessed 15.06.2018).

12. Vakhromeeva O. B. Educational and scientific value of the museum collection for teaching of art history at the history and philology faculty of the Higher Women's (Bestuzhev) Courses in St. Petersburg - Petrograd at the turn of the XIX-XX centuries, in Muzeologia a Kulturne Dedicstvo, 2018, no. 1, pp. 43-54. Available at: https://elibrary.ru/item.asp?id=32395326 (accessed 15.06.2018).

Submitted 20.07.2018; revised 20.08.2018.

The author has read and approved the final manuscript.

\begin{abstract}
About the author
Oksana B. Vakhromeeva

Dr. Sci. (History), Associate Professor, Professor of Department of the History of peoples of the countries of the Commonwealth of Independent States at St. Petersburg State University, ORCID ID 0000-0001-9936-3159,o.vahromeeva@spbu.ru
\end{abstract}




\section{Особенности преподавания \\ профессорско-преподавательской корпорации на Высших женских (Бестужевских) курсах в 1878-1918 годы}

\section{О. Б. Вахромеева}

Высшие женские (Бестужевские) курсы в Санкт-Петербурге (Петрограде), просуществовавшие с 1878 по 1918 год, в 1919 г. были объединены с бывшим Императорским (Первым Петроградским) университетом. В историографии их по праву называют женским факультетом столичного университета. Основанием тому послужила постоянная поддержка профессорско-преподавательского состава мужского университета частного высшего женского учебного заведения. Следует отметить сходство построения учебного процесса и практически идентичность (за редким исключением) учебных планов обоих университетов. Бестужевские курсы для многих профессоров и преподавателей являлись местом творческой лаборатории: в женский университет часто приглашали преподавать лучших специалистов своего дела, не обращая внимания на их молодой возраст, послужной список или увольнения в связи с несогласием с политикой того или иного министра народного просвещения. Поскольку преподавательская деятельность являлась для многих из них основной сферой самореализации, то в частном женском университете они получали значительную базу и широкие возможности. Бестужевские курсы славились своими демократическими традициями. Преподаватели играли ведущую роль в проведении фундаментальных исследований и создании научных школ. Этим они способствовали не только единению мужской и женской учебной аудитории, но и благотворно влияли на развитие самих научных знаний. Высшие женские курсы обладали превосходно оборудованными научными лабораториями, кабинетами, обширными библиотечными собраниями, что особенно влияло на развитие прикладных исследований. Кроме того, ученая корпорация, имевшая дело с молодыми, талантливыми, трудолюбивыми молодыми женщинами, получила возможность воспитать в стенах Высших женских (Бестужевских) курсов уникальную плеяду первых русских женщин-ученых, продолживших в профессиональной деятельности научные традиции своей alma mater.

Ключевые слова: Санкт-Петербургские (Петроградские) Высшие женские (Бестужевские) курсы, С. Б. Окунь, научная корпорация, университетология.

Для цитирования: Вахромеева О. Б. Публичное вторжение в частную жизнь (эвристическая ценность устных и письменных эго-документов для гендерной истории) // Запад - Восток. 2018. № 11. С. 180-191. DOI: 10.30914/2227-6874-2018-11-180-191

\section{Список литературы}

1. Вахромеева О. Б. Приглашение к пугешествию: методика исторических поездок И. М. Гревca. СПб.: Знаменитые универсанты, 2007. 56 c. URL: https:/elibrary.ru/item.asp?id=20268751 (дата обращения: 15.06.2018). 
2. Вахромеева О. Б. Духовное пространство университета. Высшие женские (Бестужевские) курсы 1878-1918 гг.: исследование и материалы. СПб.: Диада, 2003. 253 с. URL: https:/elibrary.ru/item.asp?id=20272970 (дата обращения: 15.06.2018).

3. Вахромеева О. Б. Их дань Бестужевским курсам (объединенная деятельность в 50-70-е годы XX века). СПб.: Лема, 2015. 444 c. URL: https://elibrary.ru/item.asp?id=25554623

4. Вахромеева О. Б. Воспитанные традицией. Воспоминания бывших слушательниц Бестужевских курсов. СПб.: Арт-Экспресс, 2016. 124 с. URL: https://elibrary.ru/item.asp?id=27502448 (дата обращения: 15.06.2018).

5. Вахромеева О. Б. Химия и химики на Бестужевских курсах. СПб.: Арт-Экспресс, 2017. 120 c. URL: https://elibrary.ru/item.asp?id=27661291 (дата обращения: 15.06.2018).

6. Вахромеева О. Б. Преподавание наук на Высших женских (Бестужевских) курсах (1878-1918). Со вступительным очерком «Границы женской эмансипации в дореволюционной России»: к 140-летию Бестужевских курсов. М.: Политическая энциклопедия, 2018. 903 c. URL: https:// elibrary.ru/item.asp?id=35566178 (дата обращения: 15.06.2018).

7. Егорова В. И. Первая научно-исследовательская химическая лаборатория на ВЖК / Санкт-Петербургские Высшие женские (Бестужевские) курсы. 1878-1918: сборник статей, 2-е изд. Л.: ЛГУ, 1973. С. 269-278.

8. Иванов А. Е. Ученое достоинство Российской империи. XVIII - начало XX века. Подготовка и научная аттестация профессоров и преподавателей высшей школы. М.: Новый хронограф, 2016. 656 c. URL: https://elibrary.ru/item.asp?id=28936936 (дата обращения: 15.06.2018).

9. Марголис Ю. Д. Семён Бенцианович Окунь. Жизнь историка, рассказанная его книгами, документами и свидетельствами современников. СПб.: СПбГУ, 1993. 87 с.

10. Ростовцев Е. А. Столичный университет Российской империи: ученое сословие, общество и власть (вторая половина XIX - начало XX в.). М.: Политическая энциклопедия, 2017. 903 c. URL: https://elibrary.ru/item.asp?id=29370832 (дата обращения: 15.06.2018).

11. Ananiev V. G. The Institute of Art History and the Problem of Aesthetic Education in Russia in the First Quarter of the 20th Century Muzeologia a Kulturne Dedicstvo. 2016. № 2. P. 9-20. URL: $\mathrm{https}: / /$ spbu.pure.elsevier.com/ru/publications/the-institute-of-art-history-and-the-problem-of-aestheticeducati (дата обращения: 15.06.2018).

12. Vakhromeeva O. B. Educational and scientific value of the museum collection for teaching of art history at the history and philology faculty of the Higher Women's (Bestuzhev) Courses in St. Petersburg - Petrograd at the turn of the XIX-XX centuries // Muzeologia a Kulturne Dedicstvo. 2018. № 1. P. 43-54. URL: https://elibrary.ru/item.asp?id=32395326 (дата обращения: 15.06.2018).

Статья поступила в редакциюю 20.07.2018 г.; принята к публикации 20.08.2018 г.

Автор прочитал и одобрил окончательный вариант рукописи.

\section{Об авторе}

\section{Вахромеева Оксана Борисовна}

доктор исторических наук, доцент, профессор кафедры истории народов стран Содружества Независимых Государств Института истории Санкт-Петербургского государственного университета, г. Санкт-Петербург, ORCID ID 0000-0001-9936-3159, o.vahromeeva@spbu.ru 